A SPECIAL ISSUE FOR THE $6^{\mathrm{TH}}$ SCIENTIFIC INTERNATIONAL CONFERENCE

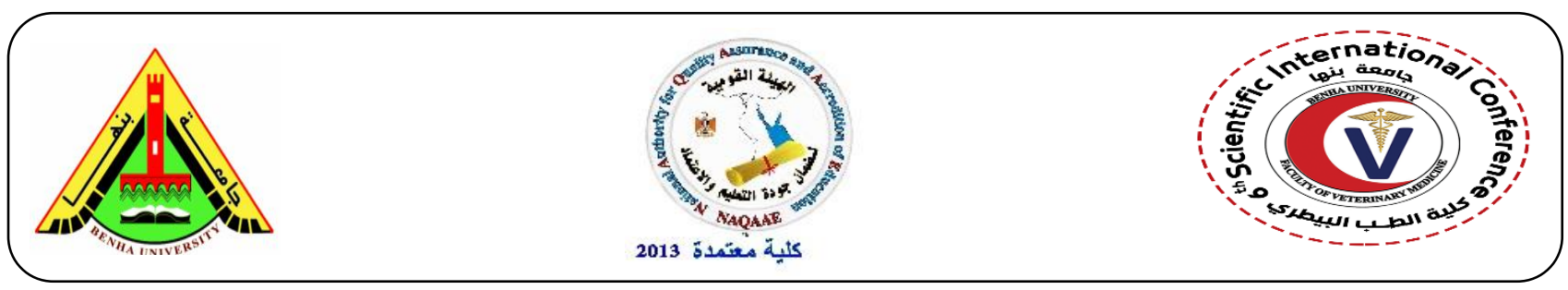

\title{
Biogenic Amines in Seafood
}

\author{
Nariman A. Helmy ${ }^{1}$, Mohamed A. Hassan², Faten S. Hassanien² and Ahmed A. Maarouf ${ }^{1}$ \\ Animal Health Research Institute, Benha Branch ${ }^{1}$.
}

Food Hygiene Control Department, Faculty of Veterinary Medicine, Benha University ${ }^{2}$

\section{A B S T R A C T}

Ninety random samples of fresh fish (Claris gariepinus, Oreochromis niloticus and Mugil cephalus, 15 of each) and shellfish (Oyster, Shrimp and Crab, 15 of each) were collected from different fish markets in Kalyobia governorate, Egypt, for determination of histamine and cadaverine levels in their tissues. The obtained results revealed that, the mean value concentrations of histamine in fish samples were $21.59 \pm 1.72 ; 18.31 \pm 1.45$ and11.64 \pm 1.19 for Claris gariepinus, Oreochromis niloticus and Mugil cephalus, respectively. Meanwhile, in shellfish samples and they were 41.75 $\pm 3.26 ; 33.08 \pm 2.57$ and $19.92 \pm 2.02$ for Oyster, shrimp and crab, respectively. In addition, mean value concentrations of cadaverine in fish samples were $17.86 \pm 1.40 ; 16.57 \pm 1.24$ and $8.94 \pm 0.76$ for Claris gariepinus, Oreochromis niloticus and Mugil cephalus, respectively. The average concentrations of cadaverine in shellfish samples were of 29.16 $\pm 2.05 ; 21.83 \pm 1.61$ and $13.09 \pm 1.14$ for Oyster, shrimp and crab, respectively. It could be inferred that regarding the products contamination, the highest histamine contamination was in oyster followed by shrimp followed by Claris gariepinus then crab then Oreochromis niloticus finally Mugil cephalus. Whereas the highest cadaverine contamination was in oyster followed by shrimp followed by Claris gariepinus then Oreochromis niloticus then crab finally Mugil cephalus.

Key words: Seafood, Residues, histamine, cadaverine (http://www.bvmj.bu.edu.eg)

(BVMJ-34(3): 279-286, 2018)

\section{INTRODUCTION:}

Seafood are a major part of food, consumed by a large percentage of population in the world, as they contain the most important nutritional components that supplies all essential elements, especially proteins and essential polyunsaturated fatty acids, required for life processes in a balanced manner and

serve as a source of energy for human beings, as well as they can contribute to heart health and children's growth and development (Sutharshiny and Sivashanthini, 2011).The biogenic amines (Bas) are low molecular weight organic bases with biological activity that are formed in foods by microbial decarboxylation of the corresponding amino acids or by transamination of aldehydes and ketones by amino acid transaminases (Zhai et al., 2012). The most important BAs, histamine, tyramine, putrescine, and cadaverine, are formed from free amino acids namely histidine, 
tyrosine, ornithine and lysine, respectively (Zarei et al., 2011). The free amino acids either occur as such in foods or may be liberated through proteolysis. In addition to the availability of precursors (amino acids), BAs accumulation in foods requires the presence of microorganisms with amino acid decarboxylases and favorable conditions for their growth and decarboxylation activity (Zarei et al., 2011). Storage temperature is the most important factor contributing to BAs formation (Chong et al., 2011). Histamine and other biogenic amines can be used as indicators for product decomposition as these compounds are detected at non-significant concentrations in fresh fish and shellfish; in addition, their formation is frequently associated with bacterial spoilage (Nurullah et al., 2007; Rezaeietal., 2007 and Kim et al., 2009).The consumption of fish and shell fish could be considered as one of the major sources of human exposure to bacterial infections and environmental contaminants (Chong et al., 2011).Moreover, high amount of amines can be produced by bacteria during amino acids decarboxylation and have been identified as one of the important agent causing seafood intoxication (Kim et al., 2009). Histamine represents the major and the main cause of scombroid (histamine) poisoning, and other biogenic amine, such as tyramine, cadaverine, and putrescine, acts as potentiates of histamine toxicity (Al Bulushi et al., 2009; Joshi and Bhoir, 2011). Therefore, the present study was conducted to evaluate the contamination levels of fish and shellfish with biogenic amines and their ability of human consumption.

\section{MATERIAL AND METHODS:}

\subsection{Collection of samples}

A total of 90 random samples of fresh fish (Clarias lazera, Oreochromis niloticus and Mugil cephalus, 15 of each) and shellfish
(Oyster, Shrimp and Crab, 15 of each) (weighted $25 \mathrm{gm}$ ) were collected from different fish markets in Kalyobia governorate, Egypt, for determination of histamine and cadaverine levels.

\subsection{Determination of biogenic amines}

All collected samples were examined for determination of two biogenic amines (histamine and cadaverine) levels on the basis of wet weight $(\mathrm{mg} / \mathrm{Kg})$ according to the protocol recommended by Krause et al. (1995) and Pinho et al. (2001).

\subsubsection{Reagents preparation:}

Dansyl chloride solution: 500mg of dansyl chloride were dissolved in $100 \mathrm{ml}$ acetone.

Standard solutions: Stock standard solutions of the tested amines were prepared as the following: $25 \mathrm{mg}$ of each standard pure amine (histamine-2HCl, tyramine-2HCl Standard solutions were added: Stock standard solutions of the tested amines were prepared as the following: add $25 \mathrm{mg}$ of each standard pure amine (histamine-2 $\mathrm{HCl}$, tyramine- $2 \mathrm{HCl}$ Standard solutions: Stock standard solutions of the tested amines were prepared as the following: add $25 \mathrm{mg}$ of each standard pure amine (histamine- $2 \mathrm{HCl}$ and tyramine-2 $\mathrm{HCl}$ ) were dissolved in $25 \mathrm{ml}$ distilled water individually.

2.2.2. Extraction of samples and formation of dansylamines (Armagan, 2006):

One hundred $\mu l$ of each stock standard solution (or sample extract) were transferred to

$50 \mathrm{ml}$ vial and dried under vacuum. About 0.5 $\mathrm{ml}$ of saturated $\mathrm{NaHCO} 3$ solution was added to the residue of the sample extract (or the standard). Vial was stoppered and carefully mixed to prevent loss- due to spattering. Carefully, $1.0 \mathrm{ml}$ dansyl chloride solution was added and mixed thoroughly using vortex 


\section{Biogenic Amines in Seafood}

mixer. The reaction mixture was incubated at $55^{\circ} \mathrm{C}$ for $45 \mathrm{~min}$. About $10 \mathrm{ml}$ of distilled water were added to the reaction mixture, then vial was stoppered and shaked vigorously using vortex mixer, the extraction of dansylated biogenic amines was carried out using $5 \mathrm{ml}$ of diethyl ether for 3times again vial was stoppered, shaked for $11.0 \mathrm{~min}$ and the ether layers were collected in a culture tube using disposable Pasteur pipette. The combined ether extracts were carefully evaporated at $35^{\circ} \mathrm{C}$ in dry bath with aid of current air. The obtained dry material was dissolved in $1 \mathrm{ml}$ methanol and $10 \mu \mathrm{l}$ were injected in High performance liquid chromatography (HPLC), data were integrated and recorded using Chemstation Software program.

\section{RESULTS:}

The obtained results in Table (1), revealed that, the minimum and the maximum histamine concentrations "mg \%" in the examined samples of fish (C. gariepinus, $O$. niloticus and $M$. cephalus) ranged from 2.44 to $39.72 ; 1.85$ to 30.94 and 1.27 to 23.50 respectively, with a mean value of $21.59 \pm$ $1.72 ; 18.31 \pm 1.45$ and $11.64 \pm 1.19$, respectively. Meanwhile, for shellfish samples (oyster, shrimp and crab) they ranged from 4.82 to $73.26 ; 3.12$ to 61.51 and 1.06 to 34.87 respectively, with a mean value of $41.75 \pm$ $3.26 ; 33.08 \pm 2.57$ and $19.92 \pm 2.02$, respectively. Moreover, 33samples, 6C. gariepinus (40\%); 3 O. niloticus (20\%); 2 M. cephalus (13.3\%); 10oyster (66.7\%); 8shrimp (53.3\%) and 4 crabs (26.7\%), were unaccepted, as they were exceeded the maximum permissible limit of histamine in fish and shellfish that should not exceed $20 \mathrm{mg} \%$ (EOS, 2010).

The results in Table (2) showed that, the minimum and the maximum cadaverine concentrations "mg \%" in the examined samples of fish (C. gariepinus, O. niloticus and M. cephalus)ranged from 1.92 to $31.06 ; 1.59$ to 28.32 and 0.84 to 20.19 respectively, with a mean value of $17.86 \pm 1.40 ; 16.57 \pm 1.24$ and $8.94 \pm 0.76$, respectively. Meanwhile, for shellfish samples (oyster, shrimp and crab) they ranged from 2.50 to $44.12 ; 2.01$ to 35.77 and 1.14 to 21.28 respectively, with a mean value of $29.16 \pm 2.05 ; 21.83 \pm 1.61$ and $13.09 \pm$ 1.14 , respectively. In addition;18samples, 4C. gariepinus $(26.7 \%) ; 2$ O. niloticus $(13.3 \%) ; 1$ M. cephalus (6.7\%); 5oyster (33.3\%); 4 shrimp (26.7\%) and 2 crabs (13.3\%), were unaccepted, as they exceeded the maximum permissible limit of cadaverine in fish and shellfish that should not exceed $20 \mathrm{mg} \%$ (EOS, 2010).

Table (1): Analytical results of histamine concentrations " $\mathrm{mg} / \mathrm{Kg}$ " in the examined samples of fish and shellfish $(\mathrm{n}=15)$.

\begin{tabular}{|c|c|c|c|c|c|}
\hline \multirow{2}{*}{$\begin{array}{l}\text { Fish and shellfish } \\
\text { species }\end{array}$} & \multirow[t]{2}{*}{ Min. } & \multirow[t]{2}{*}{ Max. } & \multirow[t]{2}{*}{ Mean \pm SEM $^{*}$} & \multicolumn{2}{|c|}{$\begin{array}{c}\text { Unaccepted Samples } \\
\text { Maximum Residual Limit } \\
(\mathrm{mg} \%) * *\end{array}$} \\
\hline & & & & No. & $\%$ \\
\hline \multicolumn{6}{|l|}{ Fish: } \\
\hline Claris gariepinus & 2.44 & 39.72 & $21.59 \pm 1.72$ & 6 & 40 \\
\hline Oreochromis niloticus & 1.85 & 30.94 & $18.31 \pm 1.45$ & 3 & 20 \\
\hline $\begin{array}{c}\text { Mugil cephalus } \\
\text { Shellfish: }\end{array}$ & 1.27 & 23.50 & $11.64 \pm 1.19$ & 2 & 13.3 \\
\hline Oyster & 4.82 & 73.26 & $41.75 \pm 3.26$ & 10 & 66.7 \\
\hline
\end{tabular}




\begin{tabular}{crrrrc} 
Shrimp & 3.12 & 61.51 & $33.08 \pm 2.57$ & 8 & 53.3 \\
Crab & 1.06 & 34.87 & $19.92 \pm 2.02$ & 4 & 26.7 \\
\hline SEM & standard error of mean \\
** Maximum Residual Limit of histamine & $(20 \mathrm{mg} \%)$ stipulated by Egyptian Organization of \\
Standardization "EOS" (2010).
\end{tabular}

Table (2): Analytical results of cadaverine concentrations "mg/Kg" in the examined samples of fish and shellfish $(n=15)$.

\begin{tabular}{|c|c|c|c|c|c|c|}
\hline \multirow{3}{*}{$\begin{array}{l}\text { Fish and } \\
\text { species }\end{array}$} & \multirow{3}{*}{ Min. } & \multirow{3}{*}{ Max. } & \multirow{3}{*}{ Mean \pm SEM. ${ }^{*}$} & \multicolumn{2}{|c|}{ Unaccepted Samples } & \multirow{3}{*}{ Limit } \\
\hline & & & & $\begin{array}{l}\text { Maximum } \\
(\mathrm{mg} \%) * *\end{array}$ & Residual & \\
\hline & & & & No. & $\%$ & \\
\hline \multicolumn{7}{|l|}{ Fish: } \\
\hline Claris gariepinus & 1.92 & 31.06 & $17.86 \pm 1.40$ & 4 & & 6.7 \\
\hline Oreochromis niloticus & 1.59 & 28.32 & $16.57 \pm 1.24$ & 2 & & 3.3 \\
\hline Mugil cephalus & 0.84 & 20.19 & $8.94 \pm 0.76$ & 1 & & 6.7 \\
\hline \multicolumn{7}{|l|}{ Shellfish: } \\
\hline Oyster & 2.50 & 44.12 & $29.16 \pm 2.05$ & 5 & & 3.3 \\
\hline Shrimp & 2.01 & 35.77 & $21.83 \pm 1.61$ & 4 & & 6.7 \\
\hline Crab & 1.14 & 21.28 & $13.09 \pm 1.14$ & 2 & & 3.3 \\
\hline
\end{tabular}

S.E.M ${ }^{*}$ = standard error of mean

** Maximum Residual Limit of cadaverine (20 mg \%) stipulated by Egyptian Organization of Standardization "EOS" (2010).

\section{DISCUSSION:}

Biogenic amines accumulation in foods requires the presence of microorganisms with amino acid decarboxylases and favorable conditions for their growth and decarboxylation activity (Zarei et al., 2011).

The high level of histamine in some investigated samples is probably related to bacterial decarboxylase activity due to quality of raw material, miss handling or other causes during their shelf- life (Koutsoumanis et al., 1999). So, when human eat fish have high level of histamine lead to acute illness called scombroid fish poisoning which characterized by facial flushing, sweating, rash, diarrhea and abdominal cramps that usually resolve after several hours without medical intervention. But severe symptoms are respiratory distress, swelling of the tongue and blurred vision that need medical treatment (CDC, 2007). In addition, scombroid poisoning is unique among the seafood toxins since it results from product mishandling rather than contamination from other trophic levels (Hungerford, 2010). The recorded results for histamine concentrations revealed that, the highest histamine 
contamination was in oyster followed by shrimp followed by Claris lazera then crab then Oreochromis niloticus finally Mugil cephalus. The results for histamine concentrations in fish samples were nearly similar to those obtained by Ekici and Alisarli (2008); Ayesh et al. (2012) and Kulawik et al. (2016). But they were disagreed with those of Lapa-Guimarães and Pickova (2004); Auerswald et al. (2006); Thaw et al. (2004); Ayesh et al. (2012); Mostafa- Azza and SalemRabab (2015); who detected histamine in fish samples with lower concentrations and with those of Tsai et al. (2006); Tao et al. (2010); Visciano et al. (2012) and El-Sayed, Huda (2014) who detected higher levels. Meanwhile, for shellfish samples, the results came in accordance with those obtained by Lin et al. (2012). But, they were disagreed with those of Yang et al. (2012) and Lago et al. (2015) who detected histamine in shellfish samples with lower concentrations; with those of Moon et al. (2011) who detected higher levels and with those of Rigg (1997) who failed to detect it in examined samples of shellfish.

The concentration of cadaverine is a good indicator of spoilage and it significantly related to post processing handling of fish products or post-harvest handling of fresh fish (Flick et al., 2001). The presence of cadaverine potentiates the toxicity of histamine. It united with nitrite to form heterocyclic carcinogenic nitrosamines, nitrosopyrrolidine and nitrosopiperidine. Also, it has a vasoactive activity that may reach to concentrations being dangerous for the most sensitive consumers (Maijala et al. 1993). The obtained results for cadaverine concentrations cleared that, the highest cadaverine contamination were in oyster followed by shrimp followed by Claris lazera then Oreochromis niloticus then crab finally Mugil cephalus .The results for cadaverine concentrations in the examined fish samples were nearly similar to those recorded by Lapa-Guimarães and Pickova (2004); Ayesh et al. (2012) and Mostafa- Azza and SalemRabab (2015). These results were disagreed with those of Thaw et al. (2004) and El-Sayed, Huda (2014) who detected cadaverine in fish samples with lower concentrations. Meanwhile; for shellfish samples, the results were disagreed with those of Yang et al. (2012) and Lago et al. (2015) who detected cadaverine in shellfish samples with lower concentrations. The obtained results declared that the cadaverine was detected in all examined samples of fish and shellfish. This declared as they are particularly good sources of free lysine (Usydus et al., 2009) and the decarboxylation of lysine leads to the formation of cadaverine that has been associated with Enterobacteriaceae count Hong et al. (2013).

Finally, the present study proved that, fish and shellfish have public health importance as the levels of biogenic amines (histamine and cadaverine) in their tissues, might be exceeded the recommended safe permissible limits stipulated by Egyptian Organization for Standardization (EOS, 2010) and must be controlled to prevent or minimize them and improve the sanitary status of fish and shellfish.

\section{REFERENCES:}

Al Bulushi, I.; Susan, P.; Hilton, C.D. and Gary, A.D., 2009. Biogenic Amines in Fish: Roles in Intoxication, Spoilage, and Nitrosamine Formation-A Review. Cri. Rev. Food Sci. Nutri., 49(4): $369-377$.

Armağan, Ö., 2006. Current analytical methods for the determination of biogenic amines in foods. Food Chemistry, 103 (4): 1475-1486. 
Auerswald, L.; Morren, C. and Lopata, A. L. ,2006. Histamine levels in seventeen species of fresh and processed South African seafood. Food Chem., 98: 231-239.

Ayesh, A. M.; Ibraheim, M. N.; El-Hakim, A. E. and Mostafa, E. A. H.,2012. Exploring the contamination level by biogenic amines in fish samples collected from markets in Thuel Saudi Arabia. African J. Microbiology Research, 6(6): 1158-1164.

CDC" Center of Disease Control and Prevention",2007. Scombroid fish poisoning associated with tuna steaks. Louisiana and Tennessee. 32: 817819.

Chong, C. Y.; Abu Bakar, F.; Russly, A. R.; Jamilah, B. and Mahyudin, N. A., 2011. The effects of food processing on biogenic amines formation. Int. Food Res. J., 18: 867-876.

EOS"Egyptian Organization for Standardization " 2010. Maximum Levels for certain contaminants in foodstuffs. No 7136/2010. Egyptian Standards, Ministry of Industry, Egypt.

Ekici, K. and Alisarli, M., 2008. Histamine formation and microbiological changes in endemic Chalcalburnus tarichi Pallas 1811 (Inci Kefali) stored at 4 degrees C. Archivos de Medicina Veterinaria.40.95:98.

El-Sayed, Huda,K., 2014. Biogenic amines in some fish products. MVSc. Thesis (Meat hygiene and Food Control), Fac. Vet. Med., Zagazig Univ.

Flick, J.G.; Oria, P.M. and Douglas, L. ,2001. Potential hazards in cold-smoked fish: Biogenic amines. Food Science J., 66(IV):1088-1099.
Hong, H.; Luo, Y.; Zhou, Z.; Bao, Y.; Lu, H. and Shen, H., 2013. Effects of different freezing treatments on the biogenic amine and quality changes of bighead carp (Aristichthys nobilis) heads during ice storage. Food Chemistry, 138:1476-1482.

Hungerford, J. M.,2010. Scombroid poisoning: A review. Toxicon., 56: 231-243.

Joshi, P.A. and Bhoir, V.S. ,2011. Study of histamine forming bacteria in commercial fish samples of Kalyan city. Int. J. Cur. Sci. Res., 1(2):39 42.

Kim, M.K.; Mah, J.H. and Hwang, H.J., 2009. Biogenic amine formation and bacterial contribution in fish, squid and shellfish. Food Chem., 116: 8795.

Koutsoumanis, K.; Lampropoulou, K. and Nychas, G.E. ,1999. Biogenic amines and sensory changes associated with the104microbial flora of Mediterranean gilt-head sea bream (Spurusaurutu) stored aerobically at 0,8 and $15^{\circ}$ C. J. Food Prot., 62:398402 .

Krause, I., Bockhardt, A., Neckerman, H., Henle, T. and Klostermeyer, H., 1995. Simultaneous determination of amino acids and biogenic amines by reversed- phase high performance liquid chromatography of the dabsyl derivatives. J. Chromatogr. A, 715: 67-79.

Kulawik, P.; Migdał, W.; Gambuś, F.; Cieślik, E.; Özoğul, $\quad$ F.; Tkaczewska, J.; Szczurowsk, K. and Wałkowska, I.,2016. Microbiological and chemical safety concerns regarding frozen fillets obtained from Pangasius sutchi 
and Nile tilapia exported to European countries.J. Sci. $\quad$ Food Agric., 96(4):1373-1379.

Lago,C.L.; Santos,V.B.;Vidal,D. and Daniel,D. ,2015. Analyze biogenic amines in salmon and shrimp by capillary electrophoresis. Tandem MS. Technical Report. Dol: 10.131401 RG.2.2.29997.49124.

Affiliation.Agilert Technologies.

Lapa-Guimarães, J. and Pickova, J., 2004.New solvent systems for thin-layer chromatographic determination of nine biogenic amines in fish and squid. J. of Chromatography A, Volume 1045, Issues 1-2, 6 223-232

Lin, C.S.; Liu, F.L.; Lee, Y.C.; Hwang, C.C. and Tsai, Y.H. ,2012. Histamine contents of salted seafood products in Taiwan and isolation of halotolerant histamine-forming bacteria. Food Chemistry. 131 .574:579.

Maijala, R.L. and Eerola, S.H.,1993. Contaminant lactic acid bacteria of dry sausage produce histamine and tyramine. Meat science.35: 387-395.

Moon, J.S.; Kim, Y.; Jan, K.I.;Ju-Cho, K.; Yang; S.; Yoon, G. and So-young, K.N.S.H. ,2011. Analysis of biogenic amines in fermented fish products consumed in Korea.Food Science and Biotechnology. 19: 168-176.

Mostafa, Azza A. and Salem, Rabab H. ,2015. Characterization of Microbiological and Nutritional Variations in Processed Mullet (Mugil cephalus) Fish. Inter. J. Microbiol. Res., 6 (2): 108-122.

Nurullah, Ş.; Senem Ş. And Güleren, O.,2007. Method optimization and separation of aromatic biogenic amines and precursor amino acids by High Performance Liquid Chromatography. Hacettepe J. Biol. and Chem., 35 (2): 129-134.

Pinho, O.; Ferreira, I.; Mendes, E.; Oliviera, B. and Ferreira, M., 2001. Effect of temperature on evolution of free amino acid and biogenic amine contents during storage of Azeitao cheese. Food Chem. ,75: 287-291.

Rezaei, M.; Jafari, H.; Sahari, M. A.; Hosseini, H.; Montazeri, N.; Parviz M. and Nazarinia, A. ,2007. Relation of biogenic amines and bacterial changes in ice-stored southern Caspian kutum (Rutilus frisii kutum). J. Food Biochemistry, 31 (4): 541-550.

Rigg, A., 1997. Biogenic Amines in Fish and Fish Products. ACT Government. ACT Health.

Sutharshiny, S. and Sivashanthini, K., 2011. Total lipid and cholesterol content in the flesh of the five important commercial fishes from waters around Jaffina Peninsula, Sri Lanka. Int. J. Biological Chem.,6: 161-169.

Tao, Z.; Sato, M.; Zhang, H.; Yamaguchi,T. and Nakano.T. ,2010. A survey of histamine content in seafood sold in markets of nine countries. J.Food Control.1:3.

Thaw, M.M.; Aung, O.; Myint, A. and Bisswanger, H., 2004. Determination of biogenic amines in different shrimp species for export. The Jour. Myan. Acad. Arts and Sci. 2(2):5.

Tsai, Y.H.; Lin, C.Y.; Chien, C.H.; Lee, M.T.; Wei, C.I. and Hwang, D.F., 2006. Histamine contents of fermented fish products in Taiwan and isolation of 
histamine forming bacteria. Food Chemistry .98 .64:70.

Usydus, Z; Richert, S.J. and Adamczyk, M. ,2009. Protein quality and amino acid profiles of fish products available in Poland. Food Chemistry, 112:139145.

Visciano, P.; Schirone,M.; Tofalo,R. and Suzzi,G.,2012. Biogenic amines in raw and processed seafood. Front. Microbio., 3:188-198.

Yang, Z.; Guang-hong,W.; Wenbin,L.;Yong,M. and Hongbing,H.,2012. Simultaneous determination of 8 biogenic amine residues in aquatic products by UltraHigh-Performance Liquid Chromatography. Food Science (3): 58.

Zarei, M.; Najafzadeh, H.; Enayati, A. and Pashmforoush, M. ,2011. Biogenic amines content of canned tuna fish marketed in Iran. American-Eurasian J. Toxicol. Sci., 3: 190-193.

Zhai, H.; Yang, X.; Li, L.; Xia, G.; Cen, J.; Huang, H. and Hao, S., 2012. Biogenic amines in commercial fish and fish products sold in Southern China. Food Control,25: 303-308. 